\title{
MicroscopyPioneers
}

\section{Pioneers in Optics: John Dallond}

From the website Molecular Expressions created by the late Michael Davidson and now maintained by Eric Clark, National High Magnetic Field Laboratory,

Florida State University, Tallahassee, FL 32306

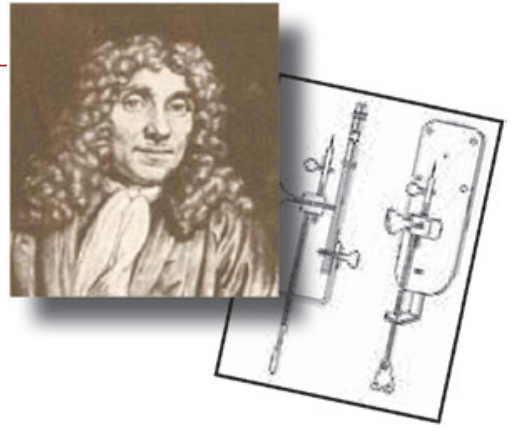

eclark@magnet.fsu.edu

\section{John Dollond}

1706-1761

John Dollond was a British telescope maker who patented the discovery of the achromatic lens in the middle eighteenth century. The story of this lens is filled with controversy because it is widely believed that Dollond was not the inventor of the achromatic lens, but learned about its properties from lens maker George Bass.

According to the literature, an attorney named Chester More Hall, with an interest in telescopes, discovered that flint glass appeared to have a greater color dispersion than crown glass did at the same magnifications. Hall reasoned that if he cemented the concave face of a flint glass lens to the convex face of a crown glass lens, he could remove the dispersion properties (and thus, chromatic aberration) from both lenses simultaneously.

During this period, telescope makers were doing a brisk business in the United Kingdom, and Hall decided

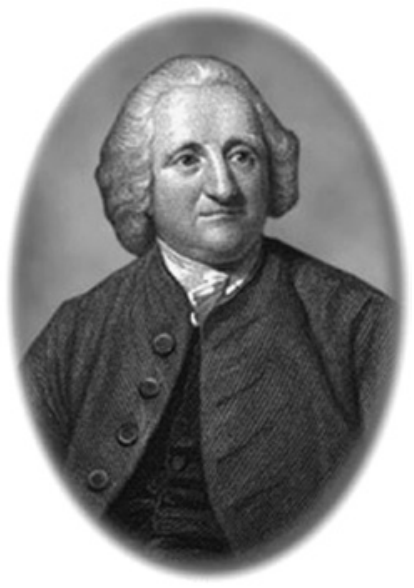
to keep his idea secret until he could hire a lens maker to fabricate an achromatic lens. Hall contacted two independent optical shops, one to grind and polish the flint glass lens and the other to make the crown glass lens. The plan was foiled when both optical shops subcontracted their jobs to the same lens maker, George Bass. Bass soon realized what was occurring and made the lenses for Hall, but he kept in mind the secret dispersion-reducing combination. Hall used the achromatic lens to fabricate his telescope sometime in the 1730s, but he never publicized his discovery and failed to patent it as well.

About 20 years later, in the 1750s, Bass met John Dollond who was also experimenting with achromatic lenses for his telescopes. When Dollond learned about Hall's secret, he quickly began experimenting with glasses of different dispersions until he had perfected his own achromatic lenses in 1758. Dollond must have been in possession of more business sense than Hall, because he succeeded in obtaining a patent for the lens. Crown glass was in common use for the fabrication of telescopes and microscopes during this period, but flint glass was much harder to work with and consequently saw fewer applications.

Dollond's tripod microscope was an intricately detailed brass rendition of a Culpeper-style dual-tripod type microscope He introduced many improvements in the basic Culpeper design, including a focusing rack that enhanced the ability to finely tune specimen focus. The microscope body was fashioned from brass tubing covered with bright red velum decorated in gold highlights. This particular model lacks the focus rack and must be focused by sliding the inner body up and down within the outer tube. Unlike the basic Culpeper models, the brass tripod legs are aligned to enhance access to the substage reflector and specimen stage.

The discovery of achromatic lenses made of flint and crown glass heralded a new era for telescope makers, but the same did not apply to the microscope. This is primarily due to technical difficulties in manufacturing the tiny achromatic compound lenses necessary for microscope objectives. The only successful objectives had very low magnifications and rather long working distances.

Dollond's reputation grew among instrument makers, and this helped his business of making telescopes. Flawless pieces of flint glass were difficult to produce, and in the late eighteenth century, glassmakers were able to supply only small quantities. Thus, supply dictated technology, and only those instrument makers who had good relationships with the glassmakers could get high-quality flint glass. Dollond, of course, had first choice of flint glass, ensuring that his shop was supplied with the necessary materials to produce the most advanced telescopes of the period.

Although Dollond held the patent on achromatic lenses, he was not particularly inclined to prosecute violators, and there were many. His oldest son, John, Jr. (1730-1821), did protest and received a court order against the violators. Dollond continued to produce fine telescopes, and his business was taken over by his sons John, Jr. and Peter after he died in 1761. 


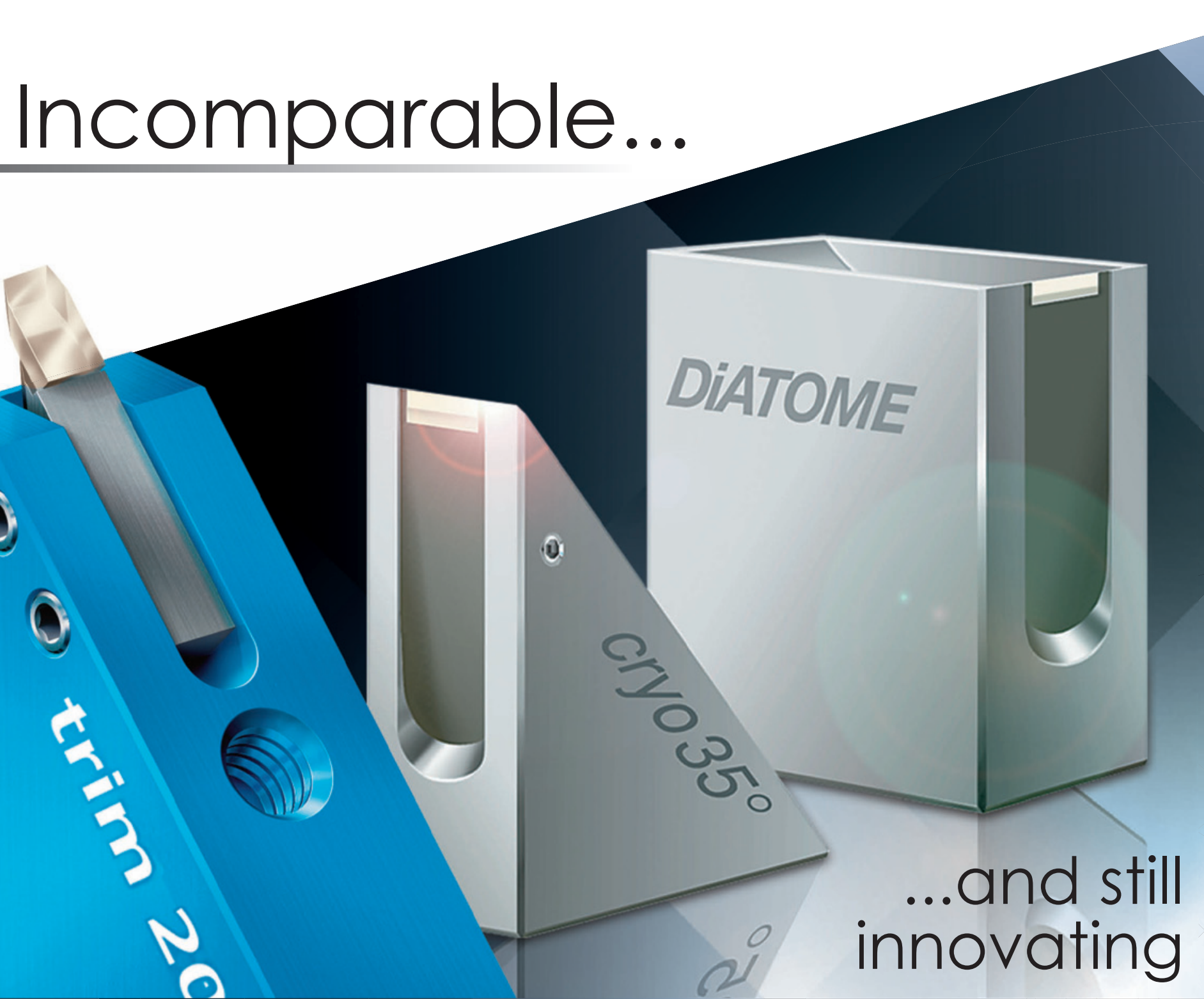

\section{DIATOME diamond knives}

ultra $45^{\circ} \cdot$ cryo $\cdot$ histo ultra $35^{\circ} \cdot$ histo jumbo cryo immuno • ultra sonic ultra AFM \& cryo AFM trimtool 20 - trimtool 45 trimtool 90

Over 40 years of development, manufacturing, and customer service

\section{DIATOME U.S.}

P.0. Box 550 • 1560 Industry Rd. • Hatfield, Pa 19440 Tel: (215) 412-8390 • Fax: (215) 412-8450

email: sgkcck@aol.com•www.emsdiasum.com
Free customer service

Sectioning tests with biological and material research specimens of all kinds. We send you the sections along with the surfaced sample, a report on the results obtained and a recommendation of a suitable knife. Complete discretion when working with proprietary samples.

\section{Re-sharpening and reworking} service

A re-sharpened Diatome diamond knife demonstrates the same high quality as a new knife. Even knives purchased in previous years can continue to be re-sharpened. The knives can be reworked into another type of knife for no extra charge, e.g. ultra to cryo or $45^{\circ}$ to $35^{\circ}$.

\section{Exchange service}

Whenever you exchange a knife we offer you a new DiATOME knife at an advantageous price. trimtool 90

Many requests from customers doing FIB cutting of biological and technical sample blocks have motivated us to relaunch the trim 90 blade:

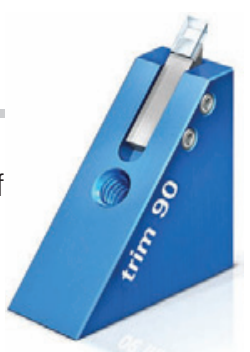

Please contact us for more information.

DiATOME manip

Our new tool for an easy handling and mounting of section ribbons!

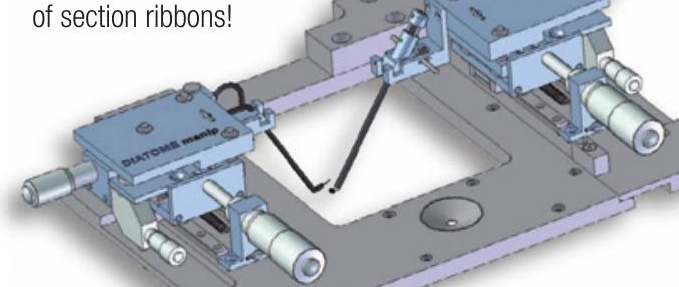

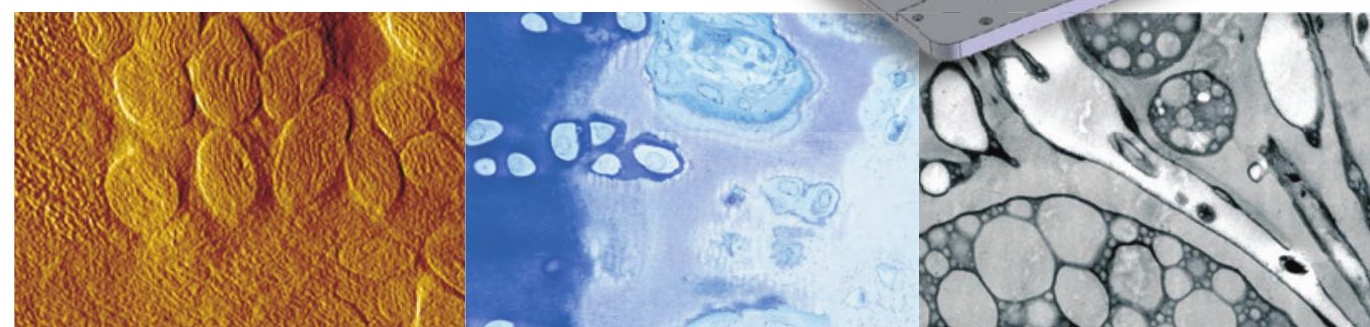

